\title{
Evaluation of phytochemical constituents and antioxidant potential of hydro-alcoholic and aqueous extracts of Murraya koenigii L. and Ficus carica L.
}

\author{
SHAH ASMA FAROOQ ${ }^{1}$, RANDHIR SINGH $^{1 *}$, VIPIN SAINI ${ }^{2}$
}

\section{${ }^{1}$ M.M. College of Pharmacy}

Maharishi Markandeshwar (Deemed to be) University

Mullana, Ambala

Haryana, India 133207

${ }^{2}$ Maharishi Markandeshwer University

Solan, H.P. India

*corresponding author: phone: +91-9896029234, e-mail: randhirsingh.dahiya@gmail.com

\section{Summary}

Introduction: Murraya koenigii L. and Ficus carica L. have been traditionally used in folk medicine for treating several diseases.

Objective: The present study was proposed to investigate the phytochemical constituents and antioxidant potential of hydro-alcoholic and aqueous extracts of leaves of M. koenigii and dried fruits of F. carica.

Methods: Phytochemical screening was performed using different methods and antioxidant activity was evaluated by measuring total phenolic content, total antioxidant capacity (TAOC), hydrogen peroxide $\left(\mathrm{H}_{2} \mathrm{O}_{2}\right)$ scavenging activity, DPPH radical-scavenging activity, reducing power assay, nitric oxide radical scavenging activity, and superoxide radical-scavenging activity.

Results: The results showed that the hydro-alcoholic and aqueous extracts of leaves of M. koenigii and dried fruits of F carica possess a significant quantity of flavonoids, saponins, terpenoids $(9.0 \%, 0.9 \%, 0.6 \%$ and $7.3 \%, 8.7 \%, 0.44 \%$, respectively) and also possess a significant antioxidant activity as evaluated by employing different antioxidant assays.

Conclusion: It may be concluded that the hydro-alcoholic and aqueous extracts of leaves of M. koenigii and dried fruits of $F$. carica exhibit significant antioxidant activity. 


\title{
Key words: antioxidant activity, Ficus carica, Murraya koenigii
}

\author{
Słowa kluczowe: aktywność antyoksydacyjna, Ficus carica, Murraya koenigii
}

\section{INTRODUCTION}

Oxidative stress is a state in which the level of oxidants increases and the level of antioxidants decreases resulting in the generation of free radicals [1]. Oxidative stress results in the production of reactive oxygen species (ROS), such as hydrogen peroxide, nitric oxide, superoxide, organic hydro peroxides, hydroxyl radicals, etc. Accumulation of ROS and reactive nitrogen species (RNS) results in a number of hazardous effects like protein oxidation, lipid peroxidation, and DNA damage [2]. Oxidative stress is known to be involved in the pathogenesis of various diseases, including hypertension, atherosclerosis, diabetes mellitus, Alzheimer disease, ischaemic diseases, malignancies and parkinsonism $[3,4]$. Therefore, the attenuation of the oxidative stress may be considered as a profound approach to diminish the progression of diseases.

Murraya koenigii L. Sprengel, (Rutaceae), is commonly called as 'Curry patta' in India [5]. Various parts of M. koenigii have been used in traditional and folk medicine for treating traumatic injury, snake bite and rheumatism. Moreover, various phytoconstituents (alkaloids and coumarin glycoside) isolated from the leaves of $M$. koenigii were found to possess antioxidant, anti-hyperlipidaemic, antifungal, antibacterial, larvicidal, anti-carcinogenic, anti-hyperglycaemic, anti-lipidperoxidative, and hypotensive activity [6]. Curry leaves are used as a stimulant, and in the management of diabetes mellitus in traditional medicine [7].

Ficus carica L. (Moraceae), known as Anjir (or fig), is widely used in Ayurveda, homoeopathy and siddha systems of medicine [8]. The bark, leaves and fruits are traditionally used to treat different disorders such as respiratory diseases, gastrointestinal diseases, diabetes, skin diseases, ulcers, dysentery and hemorrhoids [9]. F. carica has anti-inflammatory, cytotoxic, and anti-hyperlipidaemic activities. Various phytoconstituents such as amino acids, phytosterols, anthocyanins, organic acid, hydrocarbons, aliphatic alcohols, volatile components, fatty acids, phenolic components, etc. have been isolated from different parts of $F$. carica $[10,11]$.
Considering this point of view, present study was designed to estimate the antioxidant potential of hydro-alcoholic and aqueous extracts of $M$. koenigii leaves and dried fruits of F. carica.

\section{MATERIALS AND METHODS}

\section{Plant material used}

Fresh leaves of M. koenigii and dried fruits of F. carica were purchased from local market of Ambala, Haryana, India and were authenticated by Dr. K. Madhava Chetty, Department of Botany, Sri Vankateshwara University, Tirupati, India. The vouchers of plant specimen (0384 and 1296) are available in the herbarium of the University for future reference.

\section{Preparation of extracts}

Fresh leaves of $M$. koenigii were shade dried and crushed to powder. $100 \mathrm{~g}$ of powdered leaves were extracted sequentially with hydro-alcohol i.e. aqueous ethanol (40\%) and water by maceration using an electric stirrer for $48 \mathrm{hrs}$. Similarly, the fruits of F. carica were further dried, powdered and extraction (100 g) was carried out sequentially with abovementioned procedure using hydro-alcohol (40\%) and water. The extracts were then filtered and were concentrated using rotary evaporator $\left(40^{\circ} \mathrm{C}\right)$ under reduced pressure. These crude extracts were used for the phytochemical analysis and in vitro antioxidant assays.

\section{Phytochemical screening}

Phytochemical analysis was performed to determine the chemical constituents like alkaloids, fixed oils, steroids, phenolic compounds, fats, terpenoids, tannins, saponins, glycosides and flavonoids present in hydro-alcoholic and aqueous extracts of $M$. koenigii 
leaves and F. carica fruits according to the methods given by Trease, Evans, and Harborne [12, 13].

Test for alkaloids: Few $\mathrm{ml}$ of extract was added into $1 \mathrm{ml}$ of Dragendorff's reagent, $0.2 \mathrm{ml}$ of acetic acid and then noted for the formation of reddishbrown precipitates.

Test for terpenoids and steroids: Chloroform solution of the extract was shaken with concentrated sulphuric acid which on standing yields red colour indicating the presence of terpenoids. The lower layer turns to yellow on standing indicates the presence of steroids.

Test for saponins: Few $\mathrm{ml}$ of extract was added to $5 \mathrm{ml}$ of distilled water and then shaken vigorously for $3 \mathrm{~min}$ and checked for the formation of foam.

Test for glycosides: Chloroform solution of extract was added to $0.4 \mathrm{ml}$ of glacial acetic acid, few drops of ferric chloride and $0.5 \mathrm{ml}$ of concentrated sulphuric acid and observed for the formation of blue colour.

Test for flavonoids: Few $\mathrm{ml}$ of extract was treated with $1 \%$ alcoholic ferric chloride and observed for green colour formation.

Test for tannins: Few ml of extract was added with $1 \%$ gelatin solution containing $10 \%$ sodium chloride and observed for the formation of precipitates.

\section{Quantitative estimation of phytoconstituents}

Total flavonoid content [14]. $10 \mathrm{~g}$ of plant material was extracted with $100 \mathrm{ml}$ of $80 \%$ aqueous methanol in triplicate at room temperature, filtered and transferred to a crucible, dried and further weighed to constant weight.

Terpenoid content [15]. $50 \mathrm{~g}$ of plant material was macerated with methanol and water in ratio of $4: 1$ at $37^{\circ} \mathrm{C}$ for $24 \mathrm{~h}$, filtered and then concentrated at a temperature of $40^{\circ} \mathrm{C}$ and further acidified with sulphuric acid (2M). The mixture was further extracted with chloroform and non-aqueous layer was separated and dried by evaporation.

Determination of total saponins [16]. $20 \mathrm{~g}$ of plant material and $20 \%$ aqueous ethanol $(100 \mathrm{ml})$ were mixed in conical flask and heated for $4 \mathrm{~h}$ in a hot water bath $\left(55^{\circ} \mathrm{C}\right)$ with continuous mixing and filtered. The residue was further re-extracted with $20 \%$ aqueous ethanol (200 $\mathrm{ml})$. The extracts were combined and concentrated to $40 \mathrm{ml}$. The concentrate was taken in a separating funnel and diethyl ether $(20 \mathrm{ml})$ was added and vigorously shaken. Aqueous layer was further purified and ether layer was discarded. Concentrate was fractionated with n-butanol $(60 \mathrm{ml})$ repeatedly three times. Butanol fractions were combined and washed with $5 \%$ aqueous sodium chloride $(10 \mathrm{ml})$ twice. Purified butanol fractions were dried to a constant weight and saponin content was estimated as percentage.

\section{In-vitro antioxidant assays}

Estimation of total phenolic content [17]. In this method, gallic acid was used as a standard. Hydroalcoholic extract solution $(1 \mathrm{~g} / \mathrm{ml})$ was diluted with water $(46 \mathrm{ml})$ and Folin-Ciocalteau reagent $(1 \mathrm{ml})$ was added and kept for 3 min. Sodium carbonate was added and this mixture was kept with occasional shaking for $180 \mathrm{~min}$. The absorbance was measured at $760 \mathrm{~nm}$ after development of blue colour. Phenolic compounds were calculated as $\mu \mathrm{g}$ of gallic acid equivalent.

Total antioxidant capacity (TAOC) [18]. Different concentrations of extract in water $(12.5-400 \mu \mathrm{g} / \mathrm{ml})$ were prepared and extract $(0.3 \mathrm{ml})$ was mixed with reagent (mixture of sulphuric acid $(0.6 \mathrm{M})$, sodium phosphate $(28 \mathrm{mM})$ and ammonium molybdate $(4 \mathrm{mM}))(3 \mathrm{ml})$. This mixture was incubated for 90 minutes at $95^{\circ} \mathrm{C}$, cooled at a room temperature and absorbance was recorded at $695 \mathrm{~nm}$ against blank. The values of TAOC were evaluated as equivalents of ascorbic acid.

Hydrogen peroxide $\left(\mathrm{H}_{2} \mathrm{O}_{2}\right)$ scavenging activity [19]. Mixture containing sample $(1 \mathrm{ml}$; different concentrations of extracts i.e. $12.5-400 \mu \mathrm{g} / \mathrm{ml}), 0.1$ $\mathrm{M}$ phosphate buffer solution (PBS) (2.4 ml; $\mathrm{pH} 7.4$ ) and $40 \mathrm{mM} \mathrm{H}_{2} \mathrm{O}_{2}$ solution $(0.6 \mathrm{ml})$ was shaken vigorously and incubated for $10 \mathrm{~min}$ at room temperature. Absorbance was noted at $230 \mathrm{~nm}$.

Ascorbic acid was used as a reference compound. The $\mathrm{H}_{2} \mathrm{O}_{2}$ scavenging activity was calculated as follows:

$$
\% \text { inhibition }=1-\left(\mathrm{A}_{1}-\mathrm{A}_{2}\right) / \mathrm{A}_{0} \times 100
$$

where $\mathrm{A}_{0}$ : absorbance of control (water instead of sample),

$A_{1}$ : absorbance of sample,

$\mathrm{A}_{2}$ : absorbance of sample only (phosphate buffer instead of $\mathrm{H}_{2} \mathrm{O}_{2}$ solution).

The $\mathrm{IC}_{50}$ value represented the concentration that inhibited $50 \%$ of $\mathrm{H}_{2} \mathrm{O}_{2}$.

DPPH radical-scavenging activity [20.] DPPH (2,2-diphenyl-2-picryl-hydrazil) solution $(0.1 \mathrm{mM})$ 
was added in ethanol and this solution $(1 \mathrm{ml})$ and extract $(3.0 \mathrm{ml})$ (concentrations $1-5 \mu \mathrm{g} / \mathrm{ml}$ ) was incubated for 30 minutes in dark. The absorbance was recorded at $517 \mathrm{~nm}$.

Ascorbic acid was considered as standard. Test was carried out thrice. The results were expressed as $\% \mathrm{DPPH}$ scavenging effect and calculated by using the following formula:

$\%$ inhibition $=A_{0}-A_{t} / A_{0} \times 100$

where $\mathrm{A}_{0}$ : absorbance of control,

$A_{t}$ : absorbance in presence of extract.

Nitric oxide radical scavenging activity [21]. 5 $\mathrm{mM}$ of sodium nitroprusside in phosphate buffer solution and extract ( $3 \mathrm{ml}$ ) (concentrations 12.5-400 $\mu \mathrm{g} / \mathrm{ml}$ ) was incubated for 2.5 hours at $25^{\circ} \mathrm{C}$. Mixture of sulphanilamide (1\%), $\mathrm{H}_{3} \mathrm{PO}_{4}(2 \%)$ and naphthylethylenediamine dihydrochloride $(0.1 \%)$ (Greiss reagent) was added and absorbance of the chromophore formed was noted at $546 \mathrm{~nm}$.

Ascorbic acid was used as the reference compound. Percentage inhibition was calculated as:

$\%$ inhibition $=A_{0}-A_{t} / A_{0} \times 100$

where $A_{0}$ : absorbance of the control (blank, without extract),

$A_{t}$ : absorbance in the presence of the test (extract).

Reducing power assay [22]. Different concentrations of extracts $(12.5-800 \mu \mathrm{g} / \mathrm{ml})(2.5 \mathrm{ml})$ and 200 $\mathrm{mM}$ sodium phosphate buffer $(2.5 \mathrm{ml})$ and $1 \%$ potassium ferricyanide $(2.5 \mathrm{ml})$ was mixed and incubated for 20 minutes at $50^{\circ} \mathrm{C} .10 \% \mathrm{w} / \mathrm{v}$ trichloroacetic acid $(2.5 \mathrm{ml})$ was added, mixed well and centrifuged at $1000 \mathrm{rpm}$ for 8 minutes. Upper layer was separated and added into deionized water $(5 \mathrm{ml})$ and $0.1 \%$ ferric chloride $(1 \mathrm{ml})$ was added and absorbance was noted at $700 \mathrm{~nm}$.

This procedure was repeated thrice and the mean values $\pm \mathrm{SD}$ were calculated. $\mathrm{EC}_{50}$ value was calculated from concentration-absorbance graph and using ascorbic acid as standard agent.

Superoxide radical-scavenging activity: [23]. Different concentrations of extract $(12.5-400 \mu \mathrm{g} /$ $\mathrm{ml}$ ) were mixed with $50 \mathrm{mM}$ sodium carbonate (1 $\mathrm{ml}), 24 \mathrm{mM}$ NBT $(0.4 \mathrm{ml})$ and $0.1 \mathrm{mM}$ EDTA solutions $(0.2 \mathrm{ml}) .1 \mathrm{mM}$ of hydroxylamine hydrochloride $(0.4 \mathrm{ml})$ was added to start the reaction and incubated for 15 minutes at $25^{\circ} \mathrm{C}$ and absorbance recorded at $560 \mathrm{~nm}$.
The decrease in absorbance of the reaction mixture indicated increase in superoxide anion scavenging activity. Ascorbic acid was used as reference compound.

Percentage inhibition was calculated as:

$\%$ inhibition $=A_{0}-A_{t} / A_{0} \times 100$

where $\mathrm{A}_{0}$ : absorbance of control, $A_{t}$ : absorbance of samples.

Ethical approval: The conducted research is not related to either human or animal use.

\section{RESULTS AND DISCUSSION}

\section{Percentage yield and qualitative phytochemical analysis}

The percentage yield of hydro-alcoholic and aqueous extract of $M$. koenigii was found to be $24.45 \%$ and $17.7 \%$, respectively. Whereas, the percentage yield of hydro-alcoholic and aqueous extract of F. carica was found to be $34.57 \%$ and $28.42 \%$, respectively.

The qualitative analysis of hydro-alcoholic and aqueous extracts of leaves of $M$. koenigii and dried fruits of $F$. carica showed the presence of various chemical constituents (alkaloids, terpenoids, saponins, etc.) as shown in table 1 .

\section{Quantitative estimation of phytoconstituents}

The percentage of the flavonoids in M. koenigii was found to be $9.0 \%$, and that of saponins and terpenoids was found to be $0.9 \%, 0.6 \%$, respectively. However, the quantity of flavonoids in F. carica was found to be $7.3 \%$, and that of saponins and terpenoids was found to be $8.7 \%, 0.44 \%$, respectively. Various studies have confirmed the antioxidant properties of plants in respect to different flavonoids, saponins and terpenoids and these studies emphasized that the flavonoids, saponins and terpenoids can be used as potential drugs to prevent oxidative stress [24-26]. Since M. koenigii and F. carica contain a good quantity of flavonoids, saponins and terpenoids hence they can act as potent inhibitors of free radicals.

\section{Total phenol content (TPC)}


Table 1.

Qualitative analysis of hydro-alcoholic and aqueous extracts of Murraya koenigii and Ficus carica

\begin{tabular}{|c|c|c|c|c|c|c|c|c|c|c|}
\hline \multirow[b]{2}{*}{ Plant } & \multirow[b]{2}{*}{ Extract } & \multicolumn{9}{|c|}{ Phytoconstituent } \\
\hline & & Alkaloids & Carbohydrates & Glycosides & Saponins & $\begin{array}{l}\text { Fixed } \\
\text { oils and } \\
\text { fats }\end{array}$ & Terpenoids & $\begin{array}{l}\text { Phenolic } \\
\text { compounds }\end{array}$ & Proteins & Flavonoids \\
\hline \multirow{2}{*}{$\begin{array}{l}\text { Murraya } \\
\text { koenigii }\end{array}$} & $\begin{array}{l}\text { Hydro- } \\
\text { alcoholic }\end{array}$ & + & + & + & - & - & + & + & - & + \\
\hline & Aqueous & + & + & - & + & - & - & + & + & + \\
\hline \multirow{2}{*}{$\begin{array}{l}\text { Ficus } \\
\text { carica }\end{array}$} & $\begin{array}{l}\text { Hydro- } \\
\text { alcoholic }\end{array}$ & + & + & + & - & - & + & + & + & + \\
\hline & Aqueous & _ & + & _ & + & + & _- & + & _- & + \\
\hline
\end{tabular}

+ present

- absent

Phenolic compounds are among significant constituents of plant with antioxidant activity due to the presence of hydroxyl groups. These compounds produce antioxidant action by electron donation due the presence of hydroxyl groups [27]. Moreover, phenolic compounds are also reported to accelerate the synthesis of endogenous antioxidant molecules [28]. Several reports have indicated that phenolic compounds exhibit peroxide decomposition, free radical inhibition, metal inactivation or oxygen scavenging in biological systems and inhibit oxidative stress [29]. TPC in aqueous and hydro-alcoholic extract of $M$. koenigii leaves was found to be 137.01 and $172.30 \mathrm{mg} / \mathrm{g}$ gallic acid equivalent (GAE), respectively, as well as TPC in aqueous and hydro-alcoholic extracts of F. carica was found to be 214.95 and $244.38 \mathrm{mg} / \mathrm{g}$ GAE, respectively (fig. 1).

The total phenol content was found higher in hydro-alcoholic extract of both the plants and hence may exhibit a good antioxidant potential. The equation of calibration curve of gallic acid was found to be $y=0.0032 x+0.0773$ and the $R^{2}$ value was found to be $\mathrm{R}^{2}=0.9994$.

\section{Total antioxidant capacity}

Total antioxidant activity indicates the presence of water as well as fat soluble antioxidants in the extracts [30]. Total antioxidant capacity of aqueous and hydro-alcoholic extract of $M$. koenigii was found to be 488.75 and $458.98 \mu \mathrm{M} / \mathrm{g}$ ascorbic acid equivalent respectively. Total antioxidant capacity of aqueous and hydro-alcoholic extracts of $F$. carica was found to be 170.53 and $84.55 \mu \mathrm{M} / \mathrm{g}$ ascorbic acid equivalent respectively (fig. 2). The equation of calibration curve of gallic acid was found to be $y=0.0058 x+0.1846$ and the $\mathrm{R}^{2}$ value was found to be $\mathrm{R}^{2}=0.9974$.

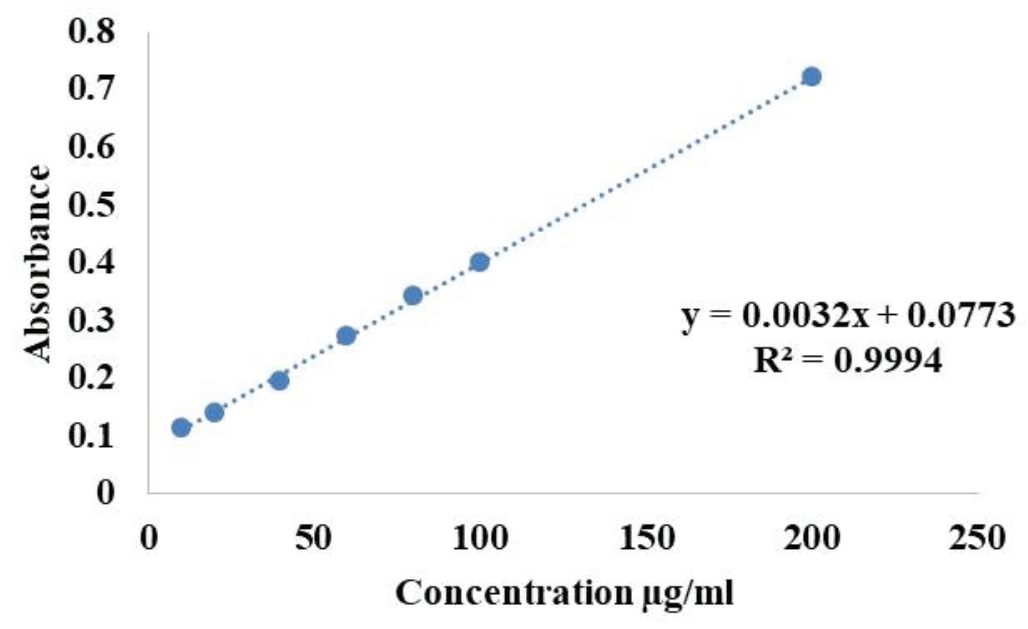

Figure 1

Standard curve of gallic acid for estimation of total phenol content 


\section{DPPH scavenging activity}

DPPH assay is considered as the most suitable and accurate method for evaluation of free radical scavenging activity of antioxidants [31]. It is a quick, simple and inexpensive method and hence widely used method to evaluate the antioxidant activity of plant and plant products. Moreover, DPPH can also be utilized for the quantification of antioxidants in complex biological systems, for solid or liquid samples. DPPH scavenging activity is based on one-electron reduction which shows the reducing activity of free radical by antioxidants [32]. At $5 \mu \mathrm{g} / \mathrm{ml}, \mathrm{DPPH}$ scavenging activity of aqueous and hydro-alcoholic extract of $F$. carica was found to be $56.53 \pm 0.10$ and $54.15 \pm 0.17 \%$, respectively, whereas that of ascorbic acid was found to be $89.48 \pm 0.25 \%$. $\mathrm{IC}_{50}$ of ascorbic acid was found to be $1.74 \mu \mathrm{g} / \mathrm{ml}$ and $\mathrm{IC}_{50}$ of aqueous and hydro-alcoholic extracts of F. carica was found to be $4.30 \mu \mathrm{g} / \mathrm{ml}$ and $4.39 \mu \mathrm{g} / \mathrm{ml}$, respectively.

At $5 \mu \mathrm{g} / \mathrm{ml}$, DPPH scavenging activity of aqueous and hydro-alcoholic extract of $M$. koenigii was found to be $63.95 \pm 0.17$ and $67.05 \pm 0.10 \%$, respectively and $\mathrm{IC}_{50}$ of aqueous and hydro-alcoholic extracts of F. carica was found to be $3.58 \mu \mathrm{g} / \mathrm{ml}$ and $3.37 \mu \mathrm{g} / \mathrm{ml}$ respectively (fig. 3 ).

These results indicate significant antioxidant activity of both extracts and so could be advantageous in the treatment of various diseases [33].

\section{Hydrogen peroxide scavenging activity}

Hydrogen peroxide $\left(\mathrm{H}_{2} \mathrm{O}_{2}\right)$ is one of free radicals which is injurious for the cells in higher concentrations and these free radicals can be scavenged by antioxidants [34]. Antioxidant activity of aqueous and hydro-alcoholic extract of F. carica against hydrogen peroxide radical was found to be $77.569 \pm 0.78$ and $79.69 \pm 0.99 \%$, respectively at $400 \mu \mathrm{g} / \mathrm{ml}$, whereas that of ascorbic acid was $97.214 \pm 0.23 \%$. $\mathrm{IC}_{50}$ of ascorbic acid was $45.62 \mu \mathrm{g} / \mathrm{ml}$ and $\mathrm{IC}_{50}$ of aqueous and hydro-alcoholic extracts of $F$. carica was found to be $217.52 \mu \mathrm{g} / \mathrm{ml}$ and $186.16 \mu \mathrm{g} / \mathrm{ml}$, respectively.

Hydrogen peroxide radical scavenging activity of aqueous and hydro-alcoholic extract of $M$. koenigii was found to be $77.44 \pm 0.78$ and $87.47 \pm 0.94 \%$, respectively, and $\mathrm{IC}_{50}$ of aqueous and hydro-alcoholic extracts of M. koenigii was found to be $160.14 \mu \mathrm{g} / \mathrm{ml}$ and $95.53 \mu \mathrm{g} / \mathrm{ml}$, respectively (fig. 4 ). The $\mathrm{IC}_{50}$ values of the extracts of $M$. koenigii were less than that of the F. carica which indicate that $M$. koenigii has better hydrogen peroxide radical scavenging activity as compared to F. carica.

\section{Reducing power assay}

The principle behind the reducing power assay method is that the compounds having reduction potential, reduce potassium ferricyanide $\left(\mathrm{Fe}^{3+}\right)$ to

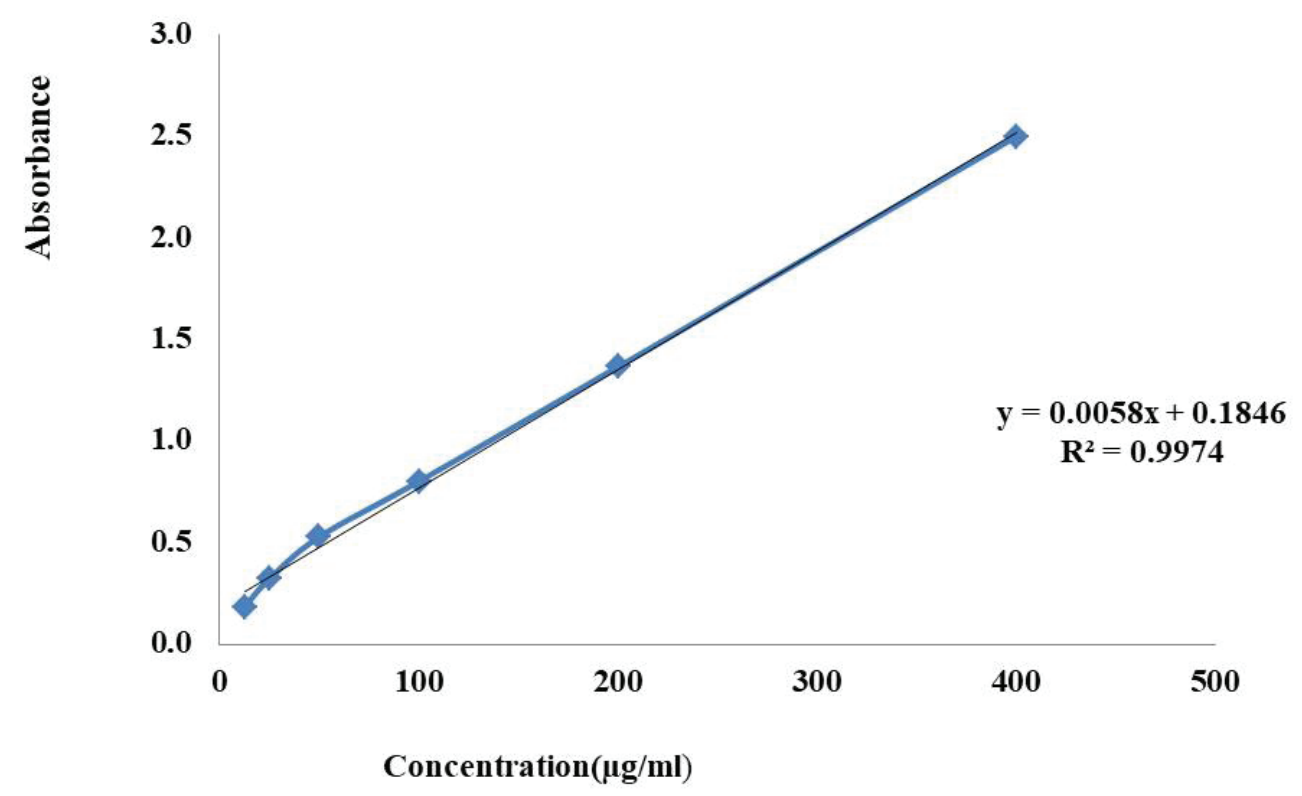

Figure 2

Standard curve of gallic acid for estimation of total phenol content 


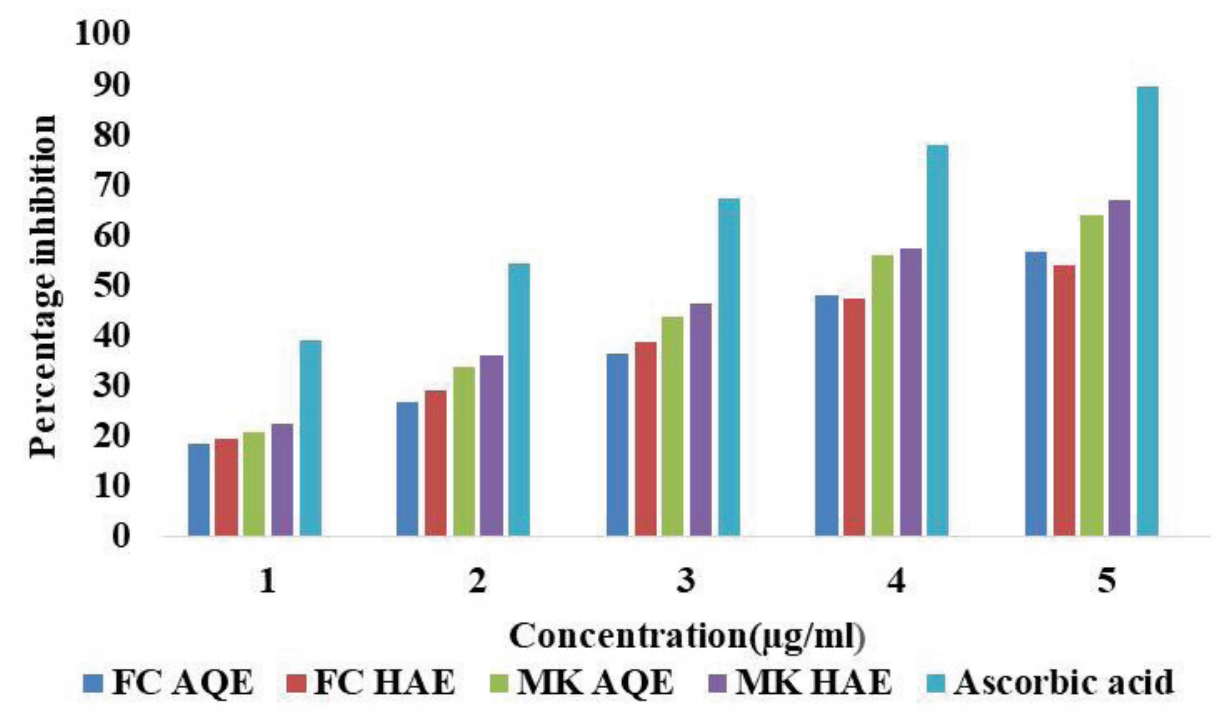

Figure 3

DPPH radical scavenging activity of hydro-alcoholic and aqueous extract of F. carica and M. koenigii.

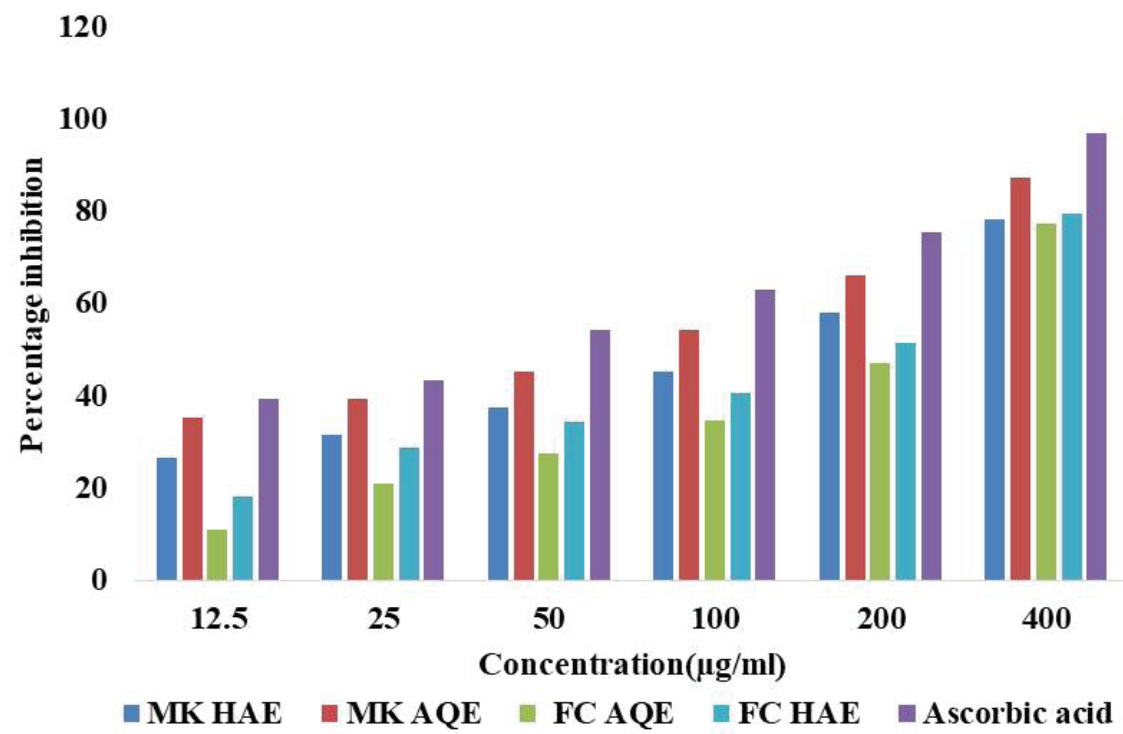

Figure 4

Hydrogen peroxide scavenging activity of hydro-alcoholic and aqueous extract of F. carica and M. koenigii.

potassium ferrocyanide $\left(\mathrm{Fe}^{2+}\right)$, which then forms ferric-ferrous complex after reacting with ferric chloride which has an absorption maximum at $700 \mathrm{~nm}$ [35]. The reducing capacity of a compound serves as an important indicator of its potential antioxidant activity [36]. $\mathrm{EC}_{50}$ was calculated and was found to be 222.44 and $315.25 \mu \mathrm{g} / \mathrm{ml}$, respectively for aqueous and hydro-alcoholic extract of $F$. carica and $20.08 \mu \mathrm{g} / \mathrm{ml}$ for ascorbic acid.

$\mathrm{EC}_{50}$ value for the aqueous and hydro-alcoholic extract of M. koenigii was found to be $135.66 \mu \mathrm{g} / \mathrm{ml}$ and $171.63 \mu \mathrm{g} / \mathrm{ml}$, respectively (fig. 5).

$\mathrm{EC}_{50}$ values of $M$. koenigii were found to be lesser than that of $F$. carica hence $M$. koenigii L. has a better reducing capability as compared to F. carica.

\section{Nitric oxide scavenging activity}

Nitric oxide scavenging method involves the decrease of NO release from sodium nitroprusside due to competition between NO and scavengers for oxygen. Antioxidant activity of aqueous and hydro-alcoholic extract of $F$ carica against nitric oxide radical was found to be $56.94 \pm 0.33$ and $65.198 \pm 0.19 \%$, respectively at 
$400 \mu \mathrm{g} / \mathrm{ml} \mathrm{IC}_{50}$ of ascorbic acid was $61.90 \mu \mathrm{g} / \mathrm{ml}$ and antioxidant activity was found to be $99.09 \pm 0.19 \%$ and $\mathrm{IC}_{50}$ of aqueous and hydro-alcoholic extract of $F$. carica was found to be $327.53 \mu \mathrm{g} / \mathrm{ml}$ and $257.05 \mu \mathrm{g} / \mathrm{ml}$.

Antioxidant activity of aqueous and hydro-alcoholic extract of $M$. koenigii against nitric oxide radical was found to be $74.56 \pm 0.33$ and $69.15 \pm 0.33 \%$, respectively, at $400 \mu \mathrm{g} / \mathrm{ml} \mathrm{IC}_{50}$ of aqueous and hydro-alcoholic extract of $M$. koenigii was found to be $199.45 \mu \mathrm{g} / \mathrm{ml}$ and $177.66 \mu \mathrm{g} / \mathrm{ml}$ (fig. 6).

\section{Superoxide scavenging activity}

The superoxide radical is present in all aerobic cells. Even though it has a mild reactivity towards the biological molecules, it may be transformed to a highly reactive and damaging hydroxyl radical [37]. Antioxidant activity of aqueous and hydro-alcoholic extract of $F$. carica against superoxide dismutase was found to be $58.53 \pm 0.47$ and $61.42 \pm 0.30$ and $\mathrm{IC}_{50}$ was found to be $304.02 \mu \mathrm{g} / \mathrm{ml}$ and $280.94 \mu \mathrm{g} / \mathrm{ml}$, respectively. Antioxidant activity of ascorbic acid was found to be $96.50 \pm 0.17 \mu \mathrm{g} / \mathrm{ml}$ and $\mathrm{IC}_{50}$ was found to be $30.03 \mu \mathrm{g} / \mathrm{ml}$.

Antioxidant activity of aqueous and hydroalcoholic extract of $M$. koenigii against superoxide dismutase was found to be $73.76 \pm 0.30$ and $79.83 \pm 0.47$ and $\mathrm{IC}_{50}$ was found to be $215.45 \mu \mathrm{g} / \mathrm{ml}$ and $186.51 \mu \mathrm{g} / \mathrm{ml}$, respectively (fig. 7).

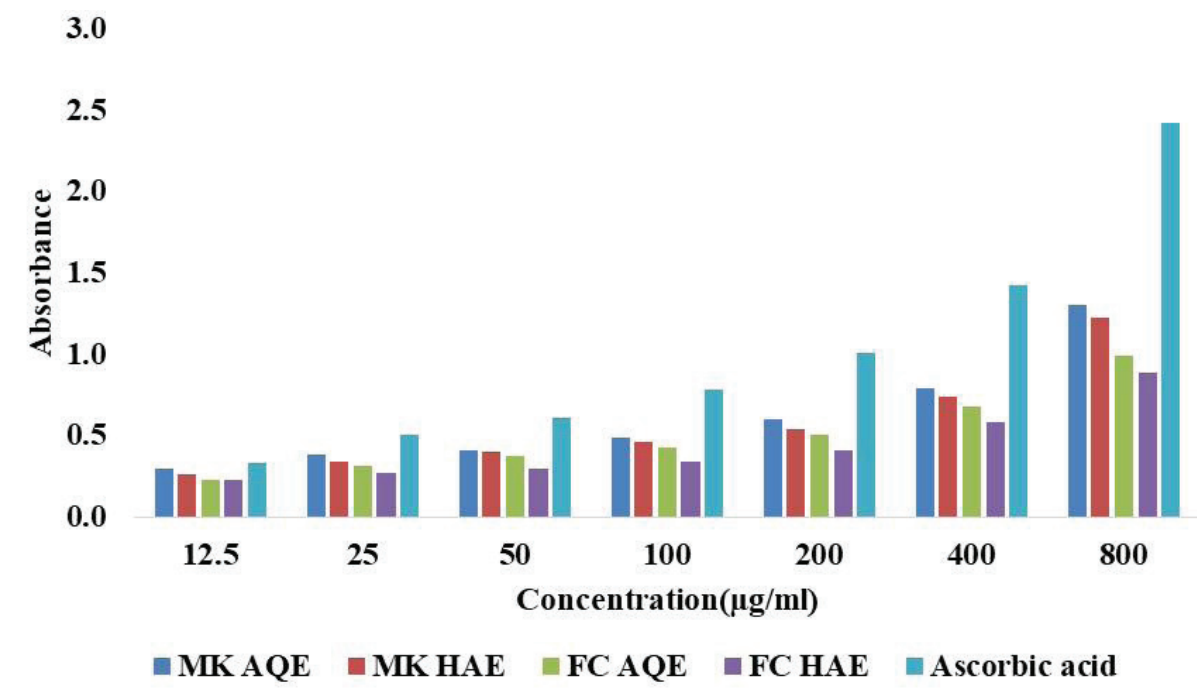

Figure 5

Reducing power assay of hydro-alcoholic and aqueous extract of F. carica and M. koenigii.

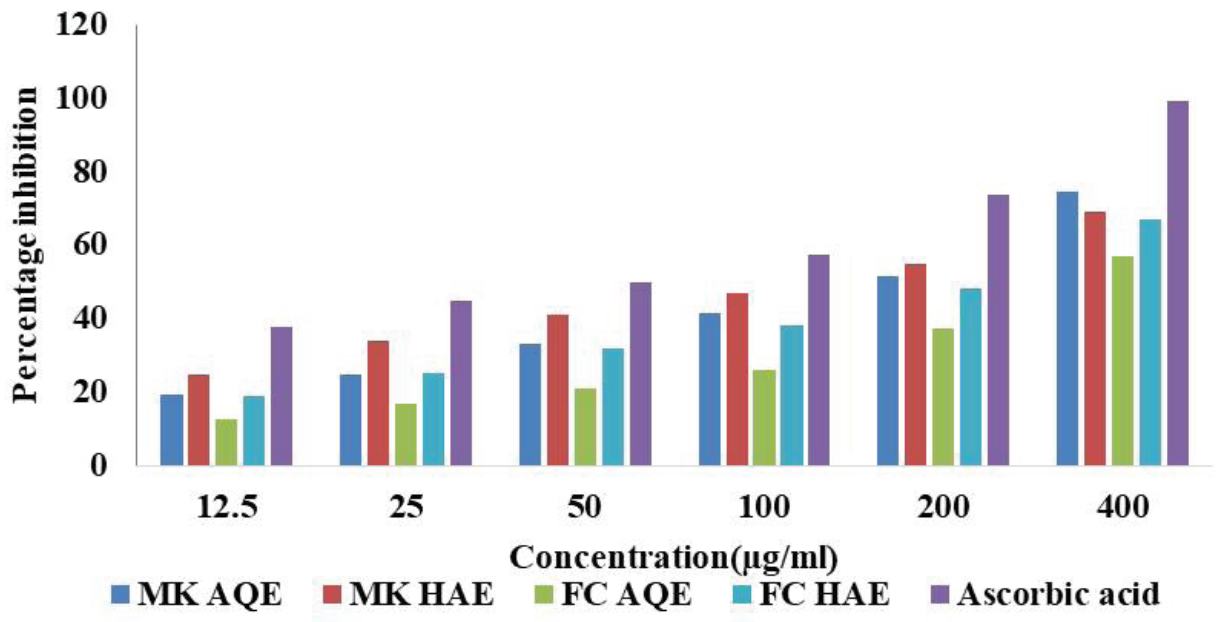

Figure 6

Nitric oxide scavenging activity of hydro-alcoholic and aqueous extract of F. carica and M. koenigii. 


\section{CONCLUSION}

From the results, it can be concluded that hydroalcoholic extracts of leaves of $M$. koenigii and dried fruits of $F$. carica have higher antioxidant activity as compared to the aqueous extracts of leaves of $M$. koenigii and dried fruits of F. carica.

Conflict of interest: Authors declare no conflict of interest.
dx:doi.org/10.2147/CIA.S158513

5. Ganesh S, Venkita SM, Savariraj S, Perumal R, Vellingiri V, Pemaiah B. Anti-diabetic potential of selected Indian traditional medicinal plants - an updated review. J Pharm Sci Res 2016; 8(160):1144-1158.

6. Satish CS, Reddy GBS. Murraya koenigii. J Pharm Biol Sci 2013; 7(6):15-18.

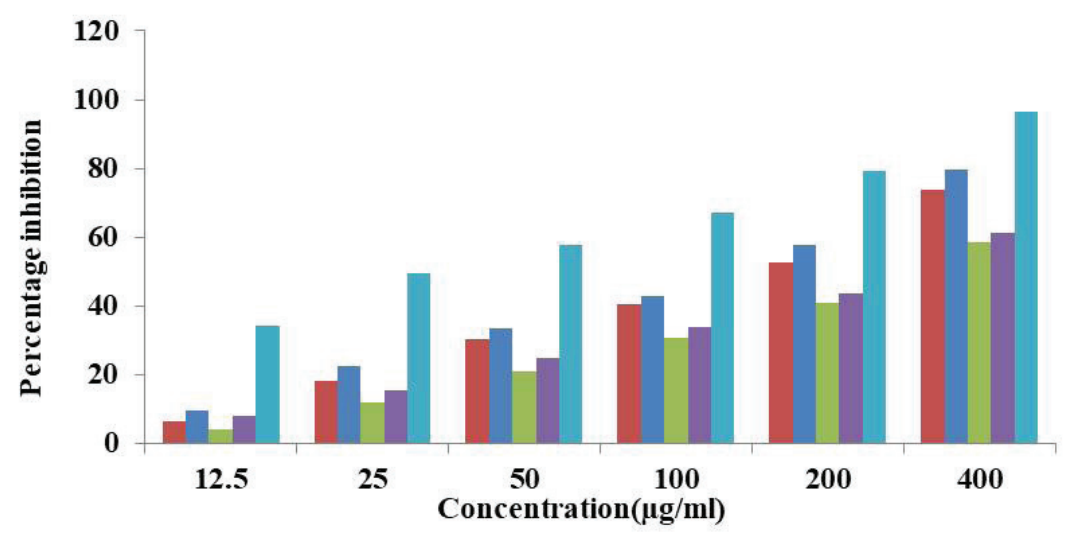

$\varpi$ MK AQE $\approx$ MK HAE $\approx$ FC AQE $\approx$ FC HAE $\approx$ Ascorbic acid

Figure 7

Superoxide scavenging activity of hydro-alcoholic and aqueous extract of F. carica and M. koenigii.

\section{REFERENCES}

1. Rahal A, Kumar A, Singh V, Yadav B, Tiwari $\mathrm{R}$, Chakraborty $\mathrm{S}$, et al.Oxidative stress, prooxidants, and antioxidants: the interplay. Bio Med Res Intern 2014. doi: http://dx.doi. org/10.1155/2014/761264

2. Newsholme P, Cruzat VF, Keane KN, Carlessi R, de Bittencourt Jr PI. Molecular mechanisms of ROS production and oxidative stress in diabetes. Biochem J 2016; 473(24):4527-4550. doi.: http:// dx:doi.org/10.1042/BCJ20160503C

3. Uttara B, Singh AV, Zamboni P, Mahajan RT. Oxidative stress and neurodegenerative diseases: a review of upstream and downstream antioxidant therapeutic options. Curr Neuropharm 2009; 7(1):65-74. doi: http://dx:doi. org/10.2174/157015909787602823

4. Liguori I, Russo G, Curcio F, Bulli G, Aran L, Della-Morte $\mathrm{D}$, et al. Oxidative stress, aging, and diseases. Clin Interv Aging 2018; 13:757. doi: http://
7. Vijayanand S. Evaluation of antidiabetic activity of Murraya koenigii on alloxan-induced diabetic rats. Int J Pharm Sci Res 2015; 6(2):1401-1405.

8. Santiagu SI, Sunil C, Stalin A, Veeramuthuuraipandiyan C, Abdullah AN, Savarimuthu I. Protective effects of Ficus carica leaves on glucose and lipids levels, carbohydrate metabolism enzymes and $\beta$-cells in type 2 diabetic rats. Pharm Biol 2017; 55(1):1074-1081. doi: http://dx:doi.org /10.1080/13880209.2017.1279671

9. Tchombé NL, Louajri A. Therapeutic effects of Ficus carica leaves: a brief review. ARPN J Sci Technol 2015; 5(1):37-41.

10. Shamkant BB, Vainav VP, Atmaram HB, Raghunath TM. Traditional uses, phytochemistry and pharmacology of Ficus carica: a review. Pharm Biol 2014; 52(11):1487-1503. doi: http://dx:doi.or g/10.3109/13880209.2014.892515

11. Krishna MG, Pallavi E, Ravi KB, Ramesh M, Venkatesh S. Hepatoprotective activity of Ficus 
carica Linn. leaf extract against carbon tetrachloride-induced hepatotoxicity in rats. DARU 2007; 15(3):162-166.

12. Trease GE, Evans WC. Textbook of pharmacognosy. $12^{\text {th }}$ ed. London 1989.

13. Harbourne JB. Phytochemical methods. A guide to modern techniques of plant analysis. London 1998.

14. Boham BA, Kocipal-Abyazan R. Flavonoids and condensed tannins from leaves of Hawaiian $\mathrm{Vac}$ cinium vaticulatum and V. calycinum. Pac Sci 1974; 48:458-463.

15. Harborne JB. Phytochemical methods. $2^{\text {nd }}$ ed. New York 1984; 3:100-117.

16. Obadoni BO, Ochuko PO. Phytochemical studies and comparative efficacy of crude extracts of some homeostatic plants in Edo and Delta States of Nigeria. Global J Pure Appl Sci 2001; 8:203-208. doi: http://dx.doi.org/10.4314/gjpas.v8i2.16033

17. Liu J, Jia L, Kan J, Jin CH. In vitro and in vivo antioxidant activity of ethanolic extract of white button mushroom (Agaricus bisporus). Food Chem Toxicol 2013; 51:310-316. doi: http://dx:doi. org/10.1016/j.fct.2012.10.014

18. Sun L, Zhang J, Lu X, Zhang L, Zhang Y. Evaluation to the antioxidant activity of total flavonoids extract from persimmon (Diospyros kaki L.) leaves. Food Chem Toxicol 2011; 49:2689-2696. doi: http://dx:doi.org/10.1016/j.fct.2011.07.042

19. Ruch RJ, Cheng SJ, Klauning JE. Prevention of cytotoxicity and inhibition of intercellular communication by antioxidant catechins isolated from Chinese green tea. Carcinogenesis 1989; 10:1003-1008.

20. Shimada K, Fujikawa K, Yahara K, Nakamura T. Antioxidative properties of xanthan on the autoxidation of soybean oil in cyclodextrin emulsion. J Agric Food Chem 1992; 40:945-948. doi: http:// dx:doi.org/10.1021/jf00018a005

21. Marcocci L, Maguire JJ, Droy MT. The nitric oxide scavenging properties of Gingko biloba extract EGb 761. Biochem Biophys Res Comm 1994; 15:748755. doi: http://dx:doi.org/10.1006/bbrc.1994.1764
22. Oyaizu M. Studies on products of browning reactions: antioxidative activities of products of browning reaction prepared from glucosamine. Jap J Nutr 1986; 44:307-315.

23. Sabu MC, Ramadasan K. Anti-diabetic activity of medicinal plants and its relationship with their antioxidant property. J Ethanopharmacol 2002; 81: 155-60. doi: http://dx:doi.org/10.1016/s03788741(02)00034-x

24. Panche AN, Diwan AD, Chandra SR. Flavonoids: an overview. J Nutr Sci 2016:5. doi: http://dx:doi. org/10.1017/jns.2016.41

25. Ghosh T, Maity TK, Sengupta P, Dash DK, Bose A. Antidiabetic and in vivo antioxidant activity of ethanolic extract of Bacopa monnieri Linn. aerial parts: A possible mechanism of action. Iran J Pharm Res 2008; 7(1):61-8. doi: http://dx:doi. org/10.22037/IJPR.2010.745

26. Jaeger R, Cuny E. Terpenoids with special pharmacological significance: a review. Nat Prod Comm 2016; 11(9):1934578X1601100946.

27. Bendary E, Francis RR, Ali HMG, Sarwat MI, El Hady S. Antioxidant and structure-activity relationships (SARs) of some phenolic and anilines compounds. Ann Agric Sci 2013; 58:173-181. doi: http://dx:doi.org/10.1016/j.aoas.2013.07.002

28. Côté J, Caillet S, Doyon G, Sylvain JF, Lacroix $\mathrm{M}$. Bioactive compounds in cranberries and their biological properties. Crit Rev Food Sci Nutr 2010; 50:666-679. doi: http://dx:doi. org/10.1080/10408390903044107

29. Aryal S, Baniya MK, Danekhu K, Kunwar P, Gurung R, Koirala N. Total phenolic content, flavonoid content and antioxidant potential of wild vegetables from western Nepal. Plants 2019; 8(4):96. doi: http://dx:doi.org/10.3390/ plants8040096

30. Aliyu AB, Ibrahim MA, Musa AM, Musa AO, Kiplimo JJ, Oyewale AO. Free radical scavenging and total antioxidant capacity of root extracts of Anchomanes difformis Engl. (Araceae). Acta Pol Pharm 2013; 70(1):115-121.

31. Prakash A. Antioxidant activity. Med Lab Anal Prog 2001; 19(2):1-6. 
32. Kedare SB, Singh RP. Genesis and development of DPPH method of antioxidant assay. J Food Sci Technol 2011; 48(4):412-422. doi: http://dx:doi. org/10.1007/s13197-011-0251-1

33. Johari MA, Khong HY. Total phenolic content and antioxidant and antibacterial activities of Pereskia bleo. Adv Pharmacol Sc 2019, 10:1-4. doi: http://dx:doi.org/10.1155/2019/7428593

34. Maswada HF, Maswada HF. Assessment of total antioxidant capacity and antiradical scavenging activity of three Egyptian wild plants. J Med Sci 2013; 13(7):546-554. doi: http://dx:doi. org/10.3923/jms.2013.546.554
35. Bhalodia NR, Nariya PB, Acharya RN, Shukla VJ. In vitro antioxidant activity of hydro-alcoholic extract from the fruit pulp of Cassia fistula Linn. Ayu 2013; 34(2):209. doi: http://dx:doi. org/10.4103/0974-8520.119684

36. Benslama A, Harrar A. Free radicals scavenging activity and reducing power of two Algerian Sahara medicinal plants extracts. Int J Herbal Med 2016; 4(6):158-161.

37. Anandjiwala S, Bagul MS, Parabia M, Rajani M. Evaluation of free radical scavenging activity of an ayurvedic formulation, Panchvalkala. Ind J Pharmac Sci 2008; 70(1):31. doi: http://dx:doi. org/10.4103/0250-474X.40328 